\title{
IS CONDITIONAL CONSERVATISM HIGHER FOR OVERSEAS-LISTED CHINESE COMPANIES ON THE HONG KONG STOCK EXCHANGE?
}

\author{
Fan-Hua Kung \\ Tamkang University, Taiwan R.O.C. \\ Kieran James \\ University of Southern Queensland, Australia \\ and \\ Chia-Ling Cheng \\ Fu Jen Catholic University, Taiwan R.O.C.
}

\begin{abstract}
$\mathrm{T}$ his paper examines the conditional accounting conservatism (Basu, 1997) of Chinese companies that are overseas listed in Hong Kong as H-shares. Due to cultural, historical and political factors, H-share companies are expected to report no more conservatively than their Chinese counterparts that are not overseas listed. The institutional setting of H-share companies, with concentrated state ownership structures, bureaucratic management incentives and political interference, are expected to impede the supply of conservative reporting. Hong Kong-listed H-share companies are exposed to the threat of litigation, competitive market forces and a strict regulatory regime in Hong Kong. However, despite these factors, we expect them to report less conservatively than native Hong Kong companies. This is because of the dominance of local institutional incentives that are culturally based. Consistent with our predictions, we find that $\mathrm{H}$-share companies report aggressively, whereas matched Chinese companies that are not overseas listed report neutrally. In addition, $H$-share companies are less conservative than native Hong Kong companies. Our evidence suggests that the location of listing has little effect on conditional conservatism because overseas-listed Chinese companies retain a significant exposure to their domestic environment.
\end{abstract}


Kung, James and Cheng

\section{INTRODUCTION}

China's economic reforms have brought the quality of financial reporting issues to the forefront. In contrast to the progress in developing its capital markets, China's accounting infrastructure has been criticised, the query being whether its institutional, cultural and political foundations can sustain a market-driven financial reporting system. Since the early 1990s, the Chinese government has implemented accounting reforms, making it clear that the development of an efficient accounting system will improve the quality of financial reporting practices. Chinese officials appear to acknowledge that a transparent and reliable financial reporting system is one of the crucial ingredients for long-term economic growth. For example, the former Chinese premier Zhu Rongji, speaking at the opening of the sixteenth World Congress of Accountants, stressed that the demand for 'open, truthful and accurate accounting information had grown stronger, that the role played by accounting has become more important and the responsibility it shoulders more significant' in a market economy (cited in Hong Kong Society of Accountants, 2003, p. 18).

This paper reflects the increasing emphasis that China places on improving the quality of financial reporting practices as part of its efforts to implement and develop the institutions needed to support sustainable economic growth. Following prior literature (Pope and Walker, 1999; Ball, Kothari and Robin, 2000; Ball, Robin and $\mathrm{Wu}, 2003$; Raonic, McLeay and Asimakopoulos, 2004; García Lara, García Osma and Mora, 2005; Huijgen and Lubberink, 2005; Bushman and Piotroski, 2006; Balkrishna, Coulton and Taylor, 2007), the focus of this paper is on international differences in conditional conservatism. Conditional conservatism is generally regarded as being an important attribute of reporting quality.

Conservatism is an established feature of accounting measurement in freemarket countries, and is one mechanism used to constrain managerial opportunistic behaviour and to enhance the reliability of financial reporting and disclosure. For this paper, accounting conservatism is defined in the conditional sense of asymmetrically timely loss recognition, which requires a higher degree of verification for recognising good news (or positive economic performance) in earnings than for recognising bad news (or negative economic performance) in earnings (see Basu, 1997, p. 4). ${ }^{1}$

This paper assesses whether conditional conservatism is more pronounced for companies that are incorporated in mainland China but are also overseas listed on the Stock Exchange of Hong Kong (SEHK) as H-shares than for non-overseas-listed Chinese companies. In further analysis, we also address whether H-share companies report as conservatively as native Hong Kong-listed companies.

We find cultural, political and historical factors continue to be dominant in China: Chinese companies with $\mathrm{H}$-shares do not report any more conservatively than nonoverseas-listed companies. ${ }^{2}$ In fact, $\mathrm{H}$-share companies report aggressively and their non-overseas-listed counterparts report neutrally. The state bureaucracy, as a major shareholder of overseas-listed Chinese companies, does not demand conservative reporting and, where it is demanded by minority shareholders, they have insufficient voice and influence to ensure that conservatism is supplied. Our results also indicate that native Hong Kong companies report significantly less aggressively/ 
more conservatively than both overseas-listed and non-overseas-listed Chinese companies, which is consistent with our prior expectations and the arguments in Bushman and Piotroski (2006). These findings suggest that the location of listing (Hong Kong) has little effect on conditional conservatism, consistent with the prior empirical results of Ball et al. (2003) and Ball, Robin and Sadka (2008).

This paper provides additional support for discriminating among institutional determinants of financial reporting quality. In addition, it adds to the literature by identifying the extent to which conditional conservatism has been incorporated into current accounting practice in China. ${ }^{3}$ In particular, it takes into account the institutional, cultural and political characteristics of a major emerging economy that is in the process of transition from communism to capitalism. Our results will have special relevance for other countries attempting the transition from communism to capitalism, such as Russia, Vietnam, the former Soviet Union republics, and the Eastern European countries.

The remainder of this paper is structured as follows. The next section develops the theory of accounting conservatism. The following sections introduce the institutional contexts and then describe the development of our hypothesis. We then present our research design and sample selection process. Further sections discuss our empirical evidence. The last section contains a brief recap and summarises the key findings of the study.

\section{ACCOUNTING CONSERVATISM}

The presence of inherent uncertainty, risk aversion and information asymmetry in the real world makes accounting conservatism a desirable feature of accounting practice at least in capitalist countries (Watts, 2003a, 2003b). In capitalist countries, economic forces, generated by the fact that various stakeholders will act in their own economic interests, create a demand for conservatism.

Devine (1963, p. 129) proposes that conservatism 'may be identified with reporting "favorable" indications with some reluctance and reporting "unfavorable" indications promptly and with unmistaken emphasis'. Recent accounting research has identified conditional and unconditional conservatism as related but distinct characteristics of accounting conservatism (Ball and Shivakumar, 2005; Beaver and Ryan, 2005). Beaver and Ryan (2005, p. 269) clarify that, under conditional conservatism, 'book values are written down under sufficiently adverse circumstances but not written up under favorable circumstances.' 'Conditional conservatism' is defined as a tendency to accelerate losses and defer gains. This characteristic of conservatism is referred to in the academic literature as 'asymmetric loss recognition timeliness' (Chandra, Wasley and Waymire, 2004; Ball and Shivakumar, 2005; Beaver and Ryan, 2005; Balkrishna et al., 2007; Lai and Taylor, 2008). Basu (1997, p. 4) describes this form of conservatism as 'accountants' tendency to require a higher degree of verification for recognizing good news than bad news in financial statements'.

Conditional conservatism exists to constrain managers' asymmetric incentives to report economic good and bad news selectively. For example, timely loss recognition 
Kung, James and Cheng

(or conditional conservatism) enhances contracting efficiency and allows stakeholders to protect their economic interests against managerial incompetence or malfeasance (Sunder, 1997). Therefore, Ball and Shivakumar (2005) and Balkrishna et al. (2007, pp. 384-385) assert that conditional conservatism is an important attribute of earnings quality because it makes financial statements more informative and useful, and thus allows stakeholders to better monitor a company's performance. Conditional conservatism gives shareholders and creditors more timely information about loss-making projects, which then allows them to take prompt remedial action (Ball et al., 2003; Balkrishna et al., 2007; Hung, Wong and Zhang, 2008).

Under uncertainty, in common law capitalist economies such as Australia, Canada, New Zealand, the United Kingdom (UK) and the United States (US), the economic interests of shareholders, creditors, auditors, regulators and other stakeholders drive accounting practices in the direction of conservative reporting and away from neutral or aggressive reporting (Sunder, 1997; Bushman and Piotroski, 2006; Roychowdhury and Watts, 2007). Stakeholders' demand for accounting conservatism affects management's supply of accounting conservatism through reporting incentives (Bushman and Piotroski, 2006, pp. 112, 130, 141; Balkrishna et al., 2007, p. 384). Institutions are responsible for the development of financial reporting practices, so the presence or absence of effective institutions, which increase reporting incentives, helps to determine the level of conditional conservatism. On the other hand, accounting conservatism is a function of the varying demands that accounting information satisfies given different institutional, legal and cultural arrangements (Ball et al., 2000, 2003; Bushman and Piotroski, 2006).

The demand for accounting conservatism is driven by the agency relationship between managers and stakeholders. Thus stakeholders' economic and political interests provide important signals about the level of conservatism which should be supplied to meet demand. Specifically, changes in economic and political interests among stakeholders generate pressure to alter such equilibrium via changes in demand and/or supply of conservatism (Bushman and Piotroski, 2006, p. 111). Other things being equal, it is expected that there will be a positive association between the demand for conservatism and the conservatism supplied. In the Chinese context, if senior managers see their most important accountability relationship as being with those further up the chain of command within the Chinese Communist Party (CCP), rather than with the 'market', then the supply of conservatism is likely to respond to this lack of demand from the party hierarchy. Since the CCP holds majority or substantial shares in overseas-listed Chinese companies, the interests of the CCP and (majority) shareholders tend to coincide in practice. Even where minority shareholders demand conservatism they may lack the voice and influence to ensure that it is supplied. Creditors probably will not demand conservatism since banks are state owned. A lack of demand for conservatism is likely to also be true for non-overseas-listed companies, but to a lesser degree due to less government involvement in their activities. Communism creates a culture that is woven into the fabric of all social relationships and becomes embedded within institutions (Zinov'ev, 1985). In the former Soviet Union we saw this process begin during Joseph Stalin's reign, from seven years after Vladimir Ilyich Lenin's 1917 communist revolution, but communism did not become fully stabilised and embedded 
until as late as the Leonid Brezhnev era in the late 1960s and 1970s (Zinov'ev, 1985). It is impossible to change communist cultures, and modes and norms of social relationships within short spaces of time, regardless of the actors' personal intentions (Zinov'ev, 1985).

\section{INSTITUTIONAL CONTEXTS AND HYPOTHESIS DEVELOPMENT}

\section{Institutional Contexts}

Recent research suggests that the demand for conservative financial reporting is influenced, either directly or in interaction with managers' reporting incentives, by a country's unique institutional environment (see Ali and Hwang, 2000; Ball et al., 2000; Ball and Shivakumar, 2005).

A growing body of research suggests that cross-country differences in legal tradition is perhaps the most important institutional factor to explain cross-country differences in developing accounting systems (Mueller, 1967; Nobes, 1983; Doupnik and Salter, 1995). As a British colony before July 1997, Hong Kong's exposure to British governance presupposes that it will adopt market-oriented common law accounting systems similar to those found in the West (Wallace and Naser, 1995). In contrast, although China generally does not have all the attributes of a code law accounting system, financial reporting practices in China are characterised as a variant of the code law model. Since inflexible (because it is slow and costly to change statutory law) code law legal traditions open up gaps between legal capabilities and commercial needs, they appear to emphasise the government's rights rather than private property rights (Beck, Demirgüç-Kunt and Levine, 2003).

La Porta, Lopez-de-Silances, Shleifer and Vishny (1998) claim that common law systems generally have stronger legal protection for outside investors and this encourages investors to enter the equity market. From Ball et al.'s (2000) point of view, a strong legal and judicial system is the most important requirement for an efficient financial reporting system because it enacts and enforces accounting and securities regulations which limit management's incentives to manipulate reported accounting information. It is also Basu's (1997) view that high demand for accounting conservatism occurs in common law countries because shareholders can resort to litigation to recover losses.

It is generally agreed that legal protection includes the rights written into regulations and laws, and effective enforcement mechanisms. Private enforcement of accounting regulations is weak in China. China has only recently passed laws to authorise class actions or similar measures to empower investors. Consequently, few lawsuits were filed against company management or auditors by shareholders until recently. This lower expected cost of shareholder litigation reduces management's incentives for reporting earnings conservatively.

In addition, La Porta et al. (1998) claim that political and bureaucratic corruption undermines a country's legal enforcement system, reduces the level of transparency in external reporting and slows financial growth (Rajan and Zingales, 2003). Government control and the regulation of economic resources provide opportunities for corruption. Thus, corruption is a continuing problem for developing 
Kung, James and Cheng

financial reporting in certain parts of Asia. In a high corruption environment, the expectation is that legal enforcement is weak and that corporate transparency and the quality of accounting information are questionable. Therefore, it is expected that countries which are generally less corrupt in business practices will disclose conservative accounting information to signal long-run reputation capital (quality) to the capital market.

The development of a country's accounting system is closely associated with the development of its financial markets. It is also argued that a strong equity market with a diverse group of shareholders generally encourages the production and disclosure of sophisticated information (Doupnik and Salter, 1995). Hong Kong is regarded as East Asia's leading international financial centre. Its well-developed and liberal financial system is at the forefront of world commerce (Wallace and Naser, 1995). Stock trading in Hong Kong began in 1866, and a formal stock exchange was established in 1891. The SEHK is the eighth largest stock market in the world, measured by market capitalisation. Hong Kong's role as an international capital window for China is growing.

China is considered a code law country and it tends to develop institutions that advance and consolidate state power. Part of the problem is that the legal system in China is weighted towards criminal prosecution and not self-regulation, a policy that protects creditors, not shareholders. According to Ali and Hwang (2000), countries that protect creditors have larger credit markets. Such countries rely for capital on a few large banks. Given little outside equity participation, companies are therefore less subject to the discipline of the market. Because large banks have access to private company information they often do not demand public disclosure.

Although the banking system in China is extensive, its equity markets are smaller than those in Hong Kong. For example, in China, market capitalisation was only 36 per cent of gross domestic product (GDP) in 2003, compared to 453 per cent in Hong Kong (Census and Statistics Department, 2003). As noted, the state-owned banks are the major capital providers in China and accounting systems are creditoriented so they often do not accurately reflect economic reality. Moreover, investor protection is weak. Finally, financial accounting in China is heavily influenced by the tax authorities. Thus, it is expected that companies in China are less transparent and demand less accounting conservatism.

On almost any objective level, accounting infrastructure, corporate transparency and investor protection in Hong Kong far exceed those found in China. In addition, Hong Kong, as a former British colony, is likely to have stronger institutions which positively influence the efficiency of the capital markets, an established legal system, strong and well-regulated financial intermediaries, and better property rights protection. It is maintained in this study that, due to the institutional differences discussed above, the shareholder orientation of common law accounting systems in Hong Kong will result in a higher demand for accounting conservatism than demand under the stakeholder model reflected in China.

\section{Hypothesis Development}

Over the last decade many Chinese companies have listed their shares on overseas stock exchanges to access external finance from deeper capital markets and 
a broader investor base (Roëll, 1996). Another advantage of overseas listing, aside from raising capital, is that it increases companies' incentives to improve performance and adopt higher standards of governance and transparency.

However, all Chinese companies must gain approval from the China Securities Regulatory Commission (CSRC) to issue shares overseas. China's overseas-listed companies are often used by the Chinese government opportunistically to 'showcase' China's industrial reforms abroad. There is a clear political aspect involved here. Significantly, only a few of China's most dynamic, successful and economically important companies are selected for listing in Hong Kong (Sun and Tong, 2000).

The headquarters and the dominant operations of these overseas-listed Chinese companies are located in mainland China. H-shares (those traded on the SEHK as opposed to A-shares, which are traded only on the mainland China exchanges) are attractive to institutional and individual investors from Hong Kong and overseas. The attraction is that $\mathrm{H}$-shares provide international investors with investment opportunities in Chinese stocks without having to be concerned about investment restrictions on ownership and language and cultural barriers, which can be major impediments for investors investing directly on the mainland. The market environment of the SEHK differs from that of China's domestic exchanges. The SEHK is well established, open and has rigorous listing requirements and information disclosure rules. This is not the case for the mainland China stock exchanges.

A Chinese company wishing to list on the SEHK must comply with the same set of listing rules and disclosure requirements as native Hong Kong companies. H-share companies can satisfy SEHK listing requirements by preparing financial statements in accordance with Hong Kong's generally accepted accounting principles (GAAP) or with international financial reporting standards (IFRSs) and the disclosure requirements of the Hong Kong Companies Ordinance. Financial statements prepared for H-share companies are audited either by the 'big four' (the largest four global brand-name accounting firms) or by another large international accounting firm.

There are several reasons why the earnings of $\mathrm{H}$-share companies might be expected to be more conservative than those of their non-overseas-listed counterparts in the absence of cultural, historical and political factors. Firstly, global accounting standards permit managers to exercise judgement so as to accurately reflect companies' contemporaneous economic performance. ${ }^{4}$ Secondly, an effective system of private litigation and market forces deepens corporate reform, strengthens corporate governance and leads to continuous improvement, management transparency and better financial results. Thirdly, the financial reports of $\mathrm{H}$-share companies are audited by international accounting firms, whereas Chinese companies listed only on the domestic exchanges are audited by local accounting firms. These Chinese accounting firms lag behind in terms of the quality of audits undertaken, lack independence, lack qualified auditors and sometimes operate in a corrupt environment (DeFond, Wong and Li, 2000; Xiao, Zhang and Xie, 2000). Chinese auditing firms may lack the abilities, independence and experience needed to make the professional judgements required to actually implement accounting conservatism in practice. In sum, $\mathrm{H}$-share companies are exposed to the threat of 
Kung, James and Cheng

litigation, competitive market forces, better auditing and a stricter regulatory and enforcement system than their non-overseas-listed counterparts.

Equally importantly, the very act of overseas listing by mainland firms on the SEHK may signal high quality reporting to investors. Ball et al. (2000) argue that high quality companies in code law countries signal quality and reduce contracting costs by listing in common law jurisdictions. Likewise, Stulz (1999) and Doidge (2004) theorise that overseas listing commits managers based in weak institutional environments to limit their consumption of private benefits in exchange for increased capital-raising ability and increased share liquidity (the 'bonding hypothesis'). This view is based on Akerlof's (1970) classic signalling model in which he argues that external third-party certification reduces information asymmetry, increases the level of trust in the marketplace and, therefore, increases the equilibrium price that higher quality products can command. Integral to Akerlof's model is the presumption that false signals of quality are costly to the signallers.

According to Bartov and Bodnar (1996) and Boone and Raman (2001), actual improved financial reporting quality reduces information asymmetry in the marketplace between informed and uninformed investors, which leads to a reduced bid-ask spread, higher quoted depth, a lower cost of capital and a higher long-run market share price. Thus, it could be argued that code law country companies listing in common law jurisdictions have an increased incentive to report conservatively. However, we argue that cultural, political and historical factors will have a greater effect on conservatism for $\mathrm{H}$-share companies than the factors just explained. As a result, the conservatism of these $\mathrm{H}$-share companies will not differ significantly from their non-overseas-listed counterparts. The majority of $\mathrm{H}$-share mainland companies are restructured state-owned enterprises (SOEs), still owned and controlled by state entities. In addition to publicly tradable shares, a typical overseas-listed Chinese company has a high portion of non-tradable shares. ${ }^{5}$ This concentrated ownership of H-shares undermines the formation of a transparent accounting system. Accountability to the CCP tends to be more important than accountability to the 'market', if not in theory then certainly in practice (Hung et al., 2008). The culture of long-established communism becomes embedded in social relationships and practices (Zinov'ev, 1985) and it is very difficult to change this quickly. We saw this in the Serbia of Slobodan Milošević in the 1990s where oneparty state communism became multi-party authoritarian nationalism, featuring powerless and confused opposition parties and continued strong media censorship (Stevanovic, 2004). As Bushman and Piotroski (2006, p. 115) argue, 'if benevolent governments intervene when they perceive that firms [and/or managers] are inefficient, firms have an incentive to look healthier through the application of less conservative accounting'. Furthermore, Bushman and Piotroski (2006, p. 109) document that, 'in countries characterised by high state involvement in the economy [even listed] firms speed recognition of good news and slow recognition of bad news in reported earnings relative to firms in countries with less state involvement.' Ms Charmaine Xie (name changed), a Shanghai native who has worked for both Chinese and international accounting firms in Shanghai, made the following observations about the incentives and reporting behaviours of Chinese listed companies (in an e-mail communication with the second-mentioned author, dated 11 April 
2008):

I have ... worked in a Shanghai stock listed company. And I know almost all the listed companies are 'reporting less conservative profits'. In China, we always say 'Don't trust the financial reports of those listed companies. They are rubbish', even though they are required to be audited by accounting firms such as [the] big 4. You can imagine what a bad reputation those companies' untrue financial reports have! In my personal opinion, this situation was caused by more economic factors than cultural factors. That's mainly because of [the] incentive-driven [culture]. Managers gotta' exaggerate the profits to pull the share price and to prove his/her good performance and achievement.

We argue that the politically connected H-share companies operate in a cultural, political and institutional environment characterised by 'crony capitalism' (Gul, 2006) where the government is willing to intervene regularly in the companies' activities to achieve political and social objectives (Gul, 2006). The CCP bureaucracy is unlikely to demand conservative reporting and hence it is unlikely to be supplied. Therefore, these companies will have a different set of incentives and constraints than native Hong Kong companies listed on the SEHK, which are totally subject to market forces.

The aforementioned literature and inferences lead to the following hypotheses:

Hypothesis 1: Chinese companies that are overseas listed in Hong Kong are expected to report no more conservatively than Chinese companies that are listed in the domestic exchanges.

Hypothesis 2: Chinese companies that are overseas listed in Hong Kong are expected to report less conservatively than native Hong Kong-listed companies.

\section{RESEARCH METHODOLOGY}

Following prior studies, Basu's (1997) conservatism model is used to explain the difference in the speed with which economic gains and losses are captured by accounting earnings. Basu defines 'conditional conservatism' as the immediate recognition of bad news and the gradual recognition of good news in such a way that bad news (negative returns) is incorporated more rapidly into accounting earnings than good news (positive returns). ${ }^{6}$ Basu's conservatism regression model takes the following form:

$$
\frac{X_{i t}}{P_{i t-1}}=\alpha_{0}+\beta_{1} D_{i_{t}}+\beta_{2} R_{i t}+\beta_{3} D_{i_{t}} \times R_{i t}+\varepsilon_{i t}
$$

where $X_{i t}$ is the earnings-per-share for company $i$ in year $t ; P_{i t-1}$ is the stock priceper-share for company $i$ at $t-1 ; R_{i t}$ is the annual stock returns for company $i$ in year $t ; 7^{7} D_{i t}$ is a dummy variable set equal to one if $R_{i t}$ is negative and zero otherwise; and $\varepsilon_{i t}$ is the disturbance term. 
Importantly, this model explains the asymmetric incorporation of contemporaneous economic gains and losses in accounting income, and hence into book values on balance sheets. ${ }^{8}$ Equation 1 posits that using accounting earnings (a lagging variable) as the dependent variable and stock returns (a leading variable) as the independent variable better estimates the slope coefficient. A bad news dummy, $D_{i t^{\prime}}$ is included in the regression to distinguish bad news from good news.

The slope coefficients $\beta_{2}$ and $\beta_{3}$ in Equation 1 are used to measure the responsiveness of reported earnings to the news captured in returns. These slope coefficients are termed 'return response coefficients'. Empirical comparisons of conservatism are based on the difference between the slope values for good news, $\beta_{2}$, and for bad news, $\left(\beta_{2}+\beta_{3}\right)$. The bad news slope coefficient is higher than the good news slope coefficient when conservatism exists. Under conditionally conservative reporting, the slope coefficient $\beta_{3^{\prime}}$, which measures the incremental response of earnings to bad news over the response to good news, is expected to be positive. ${ }^{9}$ This response reflects a stronger return-earnings relationship for companies with bad news. The intercept $a_{0}$ is also expected to be positive due to the influence of prior periods' good news in current period earnings, which is recognised gradually over future periods.

Following Beekes, Pope and Young (2004), Ball and Shivakumar (2005), Bushman and Piotroski (2006), and Balkrishna et al. (2007), this paper uses an expanded version of Basu's (1997) basic model:

$$
\begin{aligned}
\frac{X_{i t}}{P_{i t-1}} & =\alpha_{0}+\beta_{1} D_{i t}+\beta_{2} R_{i t}+\beta_{3} D_{i t} R_{i t}+\beta_{4} M A T_{i t} D_{i t}+\beta_{5} R_{i t} M A T_{i t} \\
& +\beta_{6} R_{i t} M A T_{i t} D_{i t}+\varepsilon_{i t}
\end{aligned}
$$

where $M A T_{i t}$ is a dummy variable. In the first set of tests the dummy variable is set equal to 1 if company $i$ is an $\mathrm{H}$-share company and 0 if company $i$ is a matched nonoverseas-listed Chinese company. In the second set of tests the dummy variable is set equal to 1 if company $i$ is an $\mathrm{H}$-share company and 0 if company $i$ is a native Hong Kong company. All other variables are as defined above.

In Equation 2, coefficient $\beta_{3}$ captures the marginal effect of sensitivity to bad news for companies where $M A T_{i t}$ equals 0 , and the interaction coefficient $\beta_{6}$ captures the incremental conservatism for companies where $M A T_{i t}$ equals 1 . It is also expected that, for conservative reporting, the interaction coefficient $\beta_{6}$ will be significantly positive.

\section{Sample Selection and Definition of Variables}

Both the China and the Hong Kong samples include all available company-year observations in the Taiwan Economic Journal (TEJ) database for the years 1994 to 2003. To be included in the samples, companies had to have sufficient financial data and stock return data to provide a valid data point in the estimation of the conservatism regression models. To measure the change in a company's economic income, inter-announcement stock returns, $R_{t^{\prime}}$ were used as a proxy for news. These are the annual returns calculated from nine months before the year-end $t$ to three 
months after the year-end $t$ to exclude the effect of market response to the earnings release at the previous year-end. ${ }^{10}$ The earnings variable is defined as $N I_{t}=X_{t} / P_{t-11^{\prime}}$ where $X_{t}$ is earnings-per-share in year $t$, and $P_{t-1}$ is the stock price at the beginning of the year $t$. To be consistent with earnings definitions across countries, earningsper-share is based on net income (bottom-line earnings) to control for differences in the classification of earnings across countries (Pope and Walker, 1999). Because financial companies are subject to specific regulatory requirements, the financial services industry was excluded. In addition, inactive companies were included to reduce survivorship bias. Since extraordinary items are not presented separately under Chinese GAAP, earnings-per-share was based on net income (bottom-line earnings) in the databases. Moreover, we deleted the top and bottom percentiles of the earnings and returns variables to reduce the effect of outliers on the regression results. Adoption of these sample selection procedures resulted in a final sample of 7,353 and 5,639 company-year observations for China (Shanghai and Shenzhen Stock Exchanges) and Hong Kong (SEHK) respectively.

To examine the behaviour of overseas-listed companies, Chinese companies which issued H-shares in Hong Kong were extracted from the Hong Kong SEHK sample. The overseas-listed Chinese company sample included 373 company-year observations spread throughout the sample period. We computed the stock return for a company issuing both A- and H-shares as the adjusted weighted average of $\mathrm{A}$ - and H-share returns, the weights being determined by the market value of Aor $\mathrm{H}$-shares at the beginning of the year. We did this to overcome pricing biases or inaccuracies that might exist on one of the exchanges where the company is listed. In addition, earnings-per-share for a company issuing both A- and H-shares was deflated by the weighted average of A-share and $\mathrm{H}$-share prices at the beginning of the year, the weights being determined by the number of A- or H-shares over the total number of outstanding shares of the company. In addition, the H-share company sample was matched, based on industrial affiliation and total assets, with both Chinese companies without overseas listing and with native Hong Kong companies. ${ }^{11}$

\section{RESULTS}

\section{Descriptive Statistics}

Table 1 reports the descriptive statistics for the H-share company sample. Panel A reports the raw data. The mean annual return $(R)$ for raw $\mathrm{H}$-share company data is 0.2848 with a standard deviation of 0.9598 , while the mean earnings variable $(N I)$ is 0.0543 with a standard deviation of 0.2634 .

Panel B provides summary statistics for stock returns and accounting income with adjustment of the weights. Overseas-listed company returns are generally higher than returns for those companies that are not overseas listed (shown in Table 2). The weighted mean annual return $\left(R^{w}\right)$ for the overseas-listed companies is 0.2009 with a standard deviation of 0.6758 . The accounting income of overseas-listed companies is also higher on average than for their non-overseas-listed counterparts (shown in Table 2, Panel A). The weighted mean earnings variable $\left(\mathrm{NI}^{w}\right)$ is 0.0623 
Kung, James and Cheng

TABLE I: H-SHARE SAMPLE DESCRIPTIVE STATISTICS

Panel A: H-Share Sample Raw Data ${ }^{a}$

\begin{tabular}{cccccc}
\hline & & \multicolumn{2}{c}{$\boldsymbol{R}^{\mathbf{c}}$} \\
1994 & $\boldsymbol{n}$ & Mean & Std. Dev. & Mean & Std. Dev. \\
1995 & 3 & 0.0732 & 0.0566 & -0.3945 & 0.3938 \\
1996 & 15 & 0.0787 & 0.0552 & -0.2184 & 0.2839 \\
1997 & 18 & 0.0490 & 0.0674 & 0.2438 & 0.4975 \\
1998 & 26 & 0.0192 & 0.0883 & -0.3931 & 0.1929 \\
1999 & 40 & -0.0225 & 0.2712 & -0.3233 & 0.2000 \\
2000 & 41 & 0.0513 & 0.2361 & 0.1240 & 1.5110 \\
2001 & 45 & 0.0440 & 0.5357 & 1.0977 & 1.0020 \\
2002 & 53 & 0.0243 & 0.2603 & 0.0645 & 0.2109 \\
2003 & 58 & 0.0787 & 0.1350 & -0.1449 & 0.3496 \\
Total & 373 & 0.1141 & 0.1874 & 1.0806 & 0.9571 \\
\hline
\end{tabular}

Panel B: H-Share Sample Weighted Datad

\begin{tabular}{lccccc}
\hline & \multicolumn{3}{c}{$N$ Niwe } & \multicolumn{2}{c}{$R^{w f f}$} \\
1994 & $n$ & Mean & Std. Dev. & Mean & Std. Dev. \\
1995 & 15 & 0.0734 & 0.0562 & -0.4805 & 0.1304 \\
1996 & 18 & 0.0741 & 0.0506 & -0.0197 & 0.4080 \\
1997 & 26 & 0.0391 & 0.0629 & 0.7910 & 0.7193 \\
1998 & 40 & 0.0183 & 0.0629 & -0.2365 & 0.2485 \\
1999 & 41 & 0.0124 & 0.1370 & -0.2015 & 0.3244 \\
2000 & 45 & 0.0540 & 0.1313 & 0.1311 & 0.6030 \\
2001 & 53 & 0.0959 & 0.2005 & 0.6148 & 0.6827 \\
2002 & 58 & 0.0537 & 0.1286 & -0.0118 & 0.2280 \\
2003 & 74 & 0.0685 & 0.1053 & -0.1562 & 0.3106 \\
Total & 373 & 0.0930 & 0.1492 & 0.7201 & 0.8469 \\
\hline
\end{tabular}

${ }^{a}$ The sample consists of companies which issue $\mathrm{H}$-shares in the Hong Kong stock market and have a full set of available data and accounting years falling within the period 1994-2003.

${ }^{\mathrm{b}} \mathrm{NI}\left(X_{i t} / P_{i t-1}\right)$ is defined as earnings-per-share deflated by price at the beginning of year $t$.

${ }^{\mathrm{C}} R\left(R_{i t}\right)$ denotes inter-announcement stock returns measured from May of year $t$ to April of year $t+1$.

d The data for the $\mathrm{H}$-share sample with adjustments of the weights.

${ }^{e} N I^{w}$ is defined as earnings-per-share (Hong Kong GAAP or IFRS) deflated by the beginning-of-the-year $\mathrm{H}$-share price (if the company issues only $\mathrm{H}$-shares), or a weighted average of $\mathrm{A}$ - and $\mathrm{H}$-share prices at the beginning of the year, with the weights determined by the numbers of $\mathrm{A}$ - or $\mathrm{H}$-shares over the total number of shares issued and outstanding (if the company issues both $\mathrm{A}$ - and $\mathrm{H}$-shares).

${ }^{f} R^{w}$ is the inter-announcement period $\mathrm{H}$-share return or a weighted average of $\mathrm{A}$-share and $\mathrm{H}$-share returns, with the weights determined by the market value of $\mathrm{A}$ - or $\mathrm{H}$-shares at the beginning of the year. 
TABLE 2: DESCRIPTIVE STATISTICS FOR THE CHINA SAMPLE

Panel A: Complete China Sample (Before Matching)

\begin{tabular}{lcccccc}
\hline & $n$ & Mean & Median & Std. Dev. & Min. & Max. \\
$\mathrm{N}^{\mathrm{a}}$ & 7353 & 0.0255 & 0.0186 & 0.0789 & -0.7014 & $1.756 \mathrm{I}$ \\
$\mathrm{R}^{\mathrm{b}}$ & 7353 & 0.1218 & -0.0723 & 0.6743 & -0.8617 & 8.4848 \\
\hline
\end{tabular}

Panel B: Selected Years

\begin{tabular}{crrccc}
\hline \multicolumn{5}{c}{$\mathbf{N / \mathbf { a }}$} & \multicolumn{2}{c}{$\boldsymbol{R}^{\mathbf{b}}$} & \\
Year & $\boldsymbol{n}$ & Mean & Std. Dev. & Mean & Std. Dev. \\
1994 & 249 & 0.1280 & 0.1527 & $-0.064 \mid$ & 0.3573 \\
1995 & 290 & 0.1067 & 0.1632 & 0.3131 & 0.4768 \\
1996 & 330 & 0.0706 & 0.1486 & 1.2998 & 1.1150 \\
1997 & 568 & 0.0340 & 0.0625 & 0.0147 & 0.5149 \\
1998 & 737 & 0.0271 & 0.0664 & -0.0892 & 0.4286 \\
1999 & 839 & 0.0304 & 0.0533 & 0.7582 & 0.7259 \\
2000 & 934 & 0.0134 & 0.0398 & 0.3810 & 0.8900 \\
2001 & 1089 & 0.0066 & 0.0411 & -0.2122 & 0.2209 \\
2002 & 1114 & 0.0059 & 0.0509 & -0.1903 & 0.2051 \\
2003 & 1203 & 0.0084 & 0.0608 & -0.0829 & 0.2420 \\
\hline
\end{tabular}

${ }^{\mathrm{a}} \mathrm{NI}\left(X_{i t} / P_{i t-1}\right)$ represents earnings-per-share deflated by price at the beginning of year $t$.

${ }^{\mathrm{b}} R\left(R_{i t}\right)$ denotes inter-announcement stock returns measured from May of year $t$ to April of year $t+1$.

Descriptive Statistics for the Matched Sample

Panel C: Matched China Sample (Non-Overseas-Listed Chinese Companies)

\begin{tabular}{lcccccc}
\hline \multicolumn{2}{c}{$\boldsymbol{n}$} & Mean & Median & Std. Dev. & Min. & Max. \\
$\mathrm{N} / \mathrm{a}$ & 373 & 0.0257 & 0.0190 & 0.0798 & -0.5445 & 0.8993 \\
$R^{\mathrm{b}}$ & 373 & $0.14 \mathrm{II}$ & -0.0376 & 0.6446 & -0.6594 & 4.2160 \\
\hline${ }^{\mathrm{a}} \mathrm{NI}\left(X_{i t} / P_{i t-1}\right)$ & represents earnings-per-share deflated by price at the beginning of year $t$. \\
${ }^{\mathrm{b}} \mathrm{R}\left(R_{i t}\right)$ denotes inter-announcement stock returns measured from May of year $t$ to April of year $t+\mathrm{I}$.
\end{tabular}

(0.0255) for overseas-listed (total non-overseas-listed) companies and the standard deviation is 0.1353 (0.0789).

Table 2 reports Chinese companies listed on the Shanghai Stock Exchange and the Shenzhen Stock Exchange as A-shares. ${ }^{12}$ The mean (median) annual returns $(R)$ are $0.1218(-0.0723)$, with a greater variation over the sample period and a relatively high volatility (standard deviation 0.6743 ) that is characteristic of emerging markets. ${ }^{13}$

The mean value of earnings variable (NI) is close to 0 , having mean (median) and standard deviation values of 0.0255 (0.0186) and 0.0789, while the distribution of the NI variable tends to decrease over the sample period. Both $R$ and NI are rightskewed (they exceed the medians), indicating a low level of accounting conservatism for the China sample. In addition, the standard deviation of the NI variable is always smaller than the standard deviation of $R$, consistent with Ball et al.'s (2000, p. 12) 
Kung, James and Cheng

and Ball, Kothari and Nikolaev's (2010, p. 14) argument that accounting income is a lagged function of past and present years' stock returns (i.e. 'prices lead earnings'). Panel $\mathrm{C}$ reports descriptive statistics for the matched firms only. These are not very different from those for the whole Chinese market (Panel A). Mean also exceeds median for the matched firms' net income distribution.

Table 3 reports the Hong Kong SEHK-listed companies. The mean (median) annual returns $(R)$ for the Hong Kong sample is 0.0869 (0.0505). Returns are leftskewed and display great volatility for the sample, as evidenced by the standard deviation of 0.8597 . However, the mean (median) earnings variable (NI) for the Hong Kong sample is $-0.0389(0.0505)$ and the standard deviation is 0.4449 , showing less earnings volatility. The accounting income (NI) is left-skewed. A left-skew of earnings suggests that Hong Kong companies report occasional large negative

TABLE 3: DESCRIPTIVE STATISTICS FOR THE HONG KONG SAMPLE Panel A: Complete Hong Kong Sample (Before Matching)a

\begin{tabular}{lcccccc}
\hline & $\boldsymbol{n}$ & Mean & Median & Std. Dev. & Min. & Max. \\
$\mathrm{N}^{\mathrm{a}}$ & 5636 & -0.0389 & 0.0505 & 0.4449 & -3.5368 & 5.2632 \\
$\mathrm{R}^{\mathrm{b}}$ & 5636 & 0.0869 & -0.0999 & 0.8597 & -0.9785 & 9.6796 \\
\hline
\end{tabular}

Panel B: Selected Years for Hong Kong Companies

\begin{tabular}{lllcccc}
\hline & & \multicolumn{3}{c}{$\mathbf{N l}^{\mathbf{b}}$} & \multicolumn{2}{c}{$\boldsymbol{R}^{\mathbf{c}}$} \\
1994 & 202 & 0.0947 & 0.1422 & -0.2966 & 0.2497 \\
1995 & 397 & 0.0577 & 0.3132 & 0.2320 & 0.7412 \\
1996 & 434 & 0.0550 & 0.2995 & 0.5417 & 1.0598 \\
1997 & 477 & -0.0165 & 0.3243 & -0.3786 & 0.4366 \\
1998 & 479 & -0.1567 & 0.4600 & -0.2380 & 0.1735 \\
1999 & 448 & -0.0255 & 0.4857 & 0.5119 & 1.3701 \\
2000 & 676 & -0.0335 & 0.3921 & -0.1466 & 0.6102 \\
2001 & 744 & -0.1112 & 0.4761 & 0.0551 & 0.6448 \\
2002 & 856 & -0.1048 & 0.4475 & -0.2818 & 0.4738 \\
2003 & 926 & 0.0045 & 0.3314 & 0.6341 & 0.9819 \\
\hline
\end{tabular}

${ }^{a}$ The Hong Kong sample consists of companies that have a full set of available data and accounting years falling within the period 1994-2003.

${ }^{\mathrm{b}} \mathrm{NI}\left(X_{i t} / P_{i t-1}\right)$ is earnings-per-share deflated by price at the beginning of year $t$.

${ }^{\mathrm{c}} R\left(R_{i t}\right)$ denotes inter-announcement stock returns.

Panel C: Matched Hong Kong Sample (Native Hong Kong Companies)

\begin{tabular}{lccrccc}
\hline & $\boldsymbol{n}$ & Mean & Median & Std. Dev. & Min. & Max. \\
$\mathrm{N}^{\mathrm{a}}$ & 373 & 0.0272 & 0.0790 & 0.4117 & -2.5277 & 2.7468 \\
$R^{\mathrm{b}}$ & 373 & 0.1276 & 0 & 0.7990 & -0.9334 & 7.7673 \\
\hline
\end{tabular}

${ }^{a} \mathrm{NI}\left(X_{i t} / P_{i t-1}\right)$ represents earnings-per-share deflated by price at the beginning of year $t$.

${ }^{\mathrm{b}} R\left(R_{i t}\right)$ denotes inter-announcement stock returns measured from May of year $t$ to April of year $t+1$. 
accruals consistent with the presence of conditional conservatism (Ball et al., 2000, p. 12; Balkrishna et al., 2007, p. 387; Ball et al., 2010, p. 26). Panel C reports descriptive statistics for the matched firms only. Matched firms report higher net incomes and returns than for the whole Hong Kong market (Panel A). However, the matched firms also demonstrate conditional conservatism (the median exceeds the mean for the net income distribution).

\section{Regression Results}

Table 4 presents regression results for the overseas-listed Chinese companies sample and the two matched-pairs control groups.

The first row presents the regression results for Equation 1 for the overseas-listed Chinese companies sample of 373 observations. The $\beta_{3}$ coefficient is significantly negative at the 1 per cent level $(-0.1977 ; t=-3.41)$, indicating a lack of conditional conservatism for the H-share companies sample. In fact, we have evidence of 'conditional aggression', i.e. good news is captured in earnings at a more rapid rate than bad news. The second row presents regression 1 for the first control group. This group is a matched sample of non-overseas-listed Chinese companies based on industry affiliation and total assets. The coefficient $\beta_{3}$ is not statistically significant $(0.0080 ; t=-0.18)$ for the matched sample, indicating the absence of both conditional conservatism and conditional aggression for non-overseas-listed Chinese matched companies. The third row presents the results for Equation 2 for the combined sample, including overseas-listed companies and matched non-overseas-listed companies. In this estimation, the interaction dummy coefficient $\beta_{6}$ is significantly negative at the 1 per cent level $(-0.2056 ; t=-2.70)$ and the coefficients $\left(\beta_{5}+\beta_{6}=-0.1502\right)$ are significantly negative at the 10 per cent level $(t=-1.96 ; p$-value $=0.09) .{ }^{14}$ This result implies that the matched non-overseas-listed Chinese companies report less aggressively/more conservatively than their overseas-listed counterparts; therefore, Hypothesis 1 is sustained. For nationalistic reasons, bureaucrats running overseas-listed companies have incentives to report less conservatively than senior managers of non-overseaslisted companies where government shareholdings may be lower. In fact, managers of overseas-listed companies report aggressively whereas those of their non-overseaslisted counterparts report neutrally. This finding suggests that the location of listing and accounting standards are not the primary determinants of conservatism (Ball et al., 2003). As Mao Zedong remarked back in 1957, '[r] egulations alone will not work ... men's minds must change' (quoted in Han, 1976, p. 55), and not only men's (sic) minds but also the cultural norms and practices embedded within social relationships (Zinov'ev, 1985). We are not able to report any evidence consistent with the 'bonding hypothesis' of Stulz (1999) and Doidge (2004).

The fourth row of Table 4 presents regression results for Equation 1 for the matched sample of Hong Kong companies. The incremental coefficient $\beta_{3}$ is positive and significant $(0.5473 ; t=4.03)$ for the matched sample, indicating a conservative approach to accounting by matched Hong Kong companies. The co-efficient is relatively high compared to the $0.256(t=4.00)$ reported by Bushman and Piotroski (2006, Table 2, p. 121). This may indicate that Hong Kong earnings are becoming more conservative over time, since our sample period is 1994-2003 whereas Bushman and Piotroski (2006) use 1992-2001. In addition, our small matched-firms 
Kung, James and Cheng

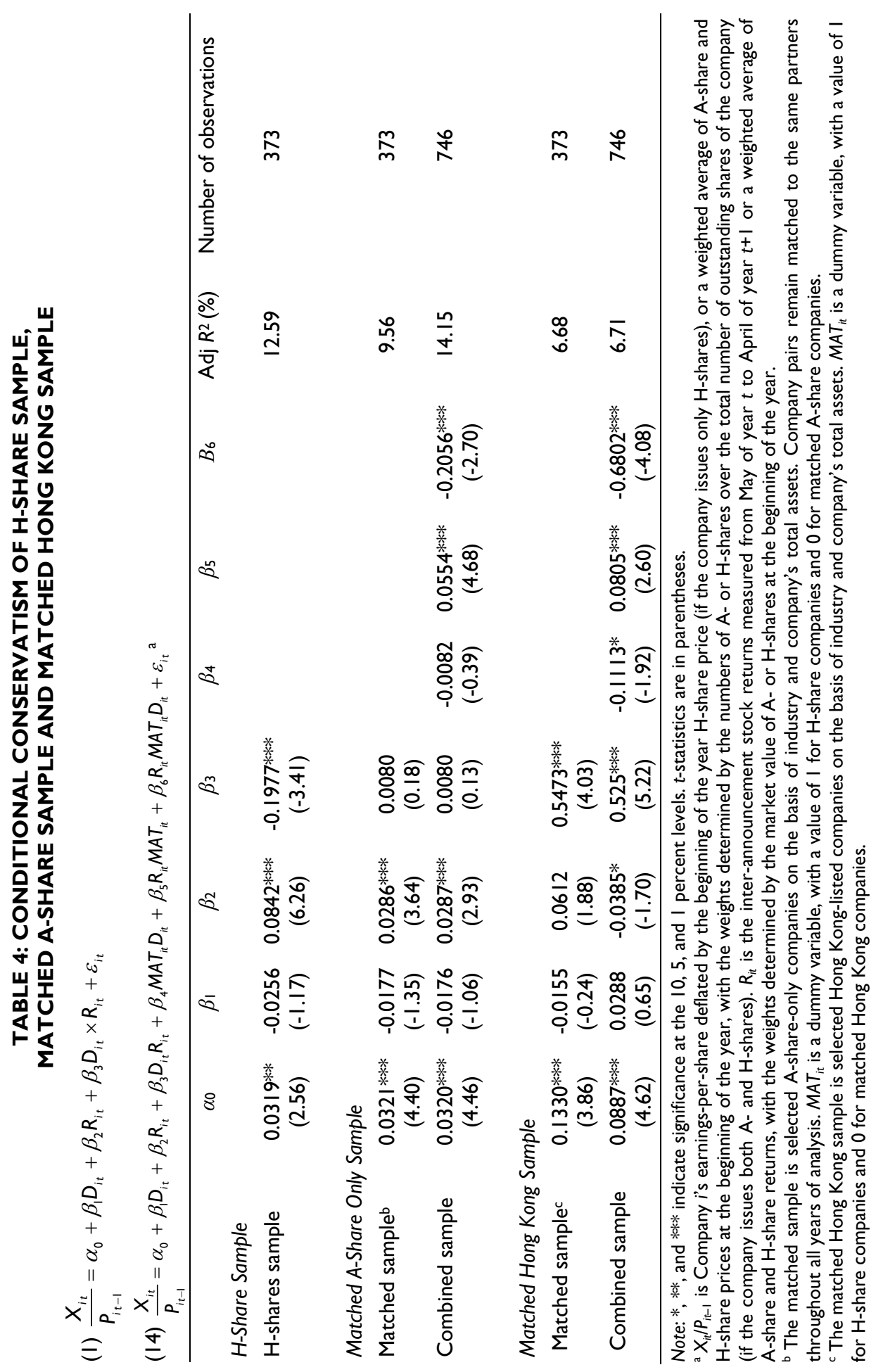


sample of $n=373$ may exhibit different conservatism than the Hong Kong market taken as a whole.

The regression results for Equation 2 for the combined sample, which includes both overseas-listed Chinese companies and matched Hong Kong companies, are given in the fifth row. The interaction dummy coefficient $\beta_{6}$ is significantly negative at the 1 per cent level $(-0.6802 ; t=-4.08)$ and the coefficients $\left(\beta_{5}+\beta_{6}=-0.5997\right)$ are significantly negative at the 5 per cent level $(t=-3.53$; $p$-value $=0.03)$, implying more aggression/less conservatism for the H-share companies. This is consistent with Bushman and Piotroski's (2006, p. 132) finding of more diffuse ownership being associated with higher conditional conservatism. H-share companies are associated with high levels of state ownership and non-tradable shares, so Hypothesis 2 is sustained. It is also consistent with Bushman and Piotroski's (2006, p. 141) finding that a high level of state ownership in the economy is associated with less conservative reporting from that country's listed companies.

\section{CONCLUDING REMARKS}

China's government has made substantial progress in recent years in enacting laws and regulations to improve reporting quality, reduce information asymmetry and, most importantly, encourage investor confidence. However, the results presented in this paper provide important additional evidence that mandating regulations alone, without a revision of the overall infrastructure, incentives and culture, is not sufficient to generate demand for conservative reporting, especially within countries with embedded communist cultures.

We have explored the earnings conservatism of $\mathrm{H}$-share companies. The results presented in this paper indicate that $\mathrm{H}$-share companies are not significantly more conservative than Chinese companies that are not overseas listed. In fact, $\mathrm{H}$-share companies report aggressively and their non-overseas-listed counterparts report neutrally. Both overseas-listed and non-overseas-listed Chinese companies report more aggressively/less conservatively than native Hong Kong companies listed on the SEHK.

These findings suggest that the location of listing has little effect on accounting conservatism because overseas-listed Chinese companies retain a significant exposure to their domestic institutional environment and culture. There are few institutional characteristics in the Chinese economy which provide incentives for management to supply accounting conservatism. Whilst minority shareholders might demand conservatism, the CСP bureaucracy as a major shareholder and owner of the banks does not. The evidence presented in this paper shows consistently that the demand for accounting conservatism arises endogenously in the institutional and cultural contexts of a country and its companies (Ball et al., 2003; Bushman and Piotroski, 2006; Ball et al., 2008; Ball et al., 2010). As Bushman and Piotroski (2006, p. 141) conclude, 'firms in countries with political economies characterized by ... high state ownership of enterprises both speed the recognition of good news and slow the recognition of bad news in earnings relative to firms in 
Kung, James and Cheng

countries with less political involvement in the economy.' We present no evidence consistent with the 'bonding hypothesis' of Stulz (1999) and Doidge (2004).

Our results are not surprising because, in a country with many elements of communism (or at least communist residues in the area of cultural norms within social relationships) present, reporting losses rapidly to the capital market may not be considered a matter of urgency. Full or excess employment, social order and social stability are likely to be regarded as more important objectives by the CCP. In mainland China, the 'economic' is rarely separated from the 'social' and the 'political'. Instead, what we observe in practice is a complex and somewhat contradictory synthesis of all of these aspects. Accountability to those higher up the chain of command in the $\mathrm{CCP}$, in practice if not in theory, remains more important than accountability to the 'market', especially for overseas-listed companies where government shareholdings are higher. The rise of Dengism and its associated nationalism has meant that overseas-listed companies are seen as 'showcase' companies (Hung et al., 2008). The large and stable reported profits of overseaslisted companies are presented and viewed as evidence of the startling economic transformation of China since 1949 and even more so since 1978. In reality, however, the absence of conservatism in China suggests that Mao-era incentives to overstate production outputs, so characteristic of the 'Great Leap Forward' campaign of the 1950s, still exert an important cultural influence over financial reporting in China today. Lenin once remarked that there is no historical precedent for a peaceful transition from capitalism to communism. The road back to capitalism is probably not much easier. The physical Berlin Wall is easy enough to dismantle but it is harder to dismantle the Berlin Wall inside people's minds (Zinov'ev, 1985). Our results should have special relevance for other countries attempting the transition from communism to capitalism, such as Russia, Vietnam, the former Soviet Union republics and the countries of Eastern Europe.

\section{ACKNOWLEDGEMENTS}

We gratefully acknowledge the helpful advice of Ray Ball (by e-mail), David Emanuel, Janice How, Mingyi Hung, Ralph Kober, Cheng Lai, Richard Lee, Jenny Kwai-Sim Leung, Matt Pinnuck, Brad Potter, Alan Ramsay (Accounting and Finance Association of Australia and New Zealand (AFAANZ) Conference 2008 discussant), Stephen Taylor, Peter Wells, Jilnaught Wong, Norman Wong, Henry Wu, Charmaine Xie (name changed), conference participants at AFAANZ Conference 2008, and seminar participants at the University of Auckland and the University of Melbourne. Initial discussions with Professor Pat Addison, Professor John Neilson and Professor Greg Tower proved instrumental to the development of the research ideas. The usual disclaimer applies. We also thank Eileen O'Brien of Blackhall Publishing and the editors of the Irish Accounting Review for their advice and assistance in formatting the final paper. 
Is Conditional Conservatism Higher for Overseas-Listed Chinese Companies?

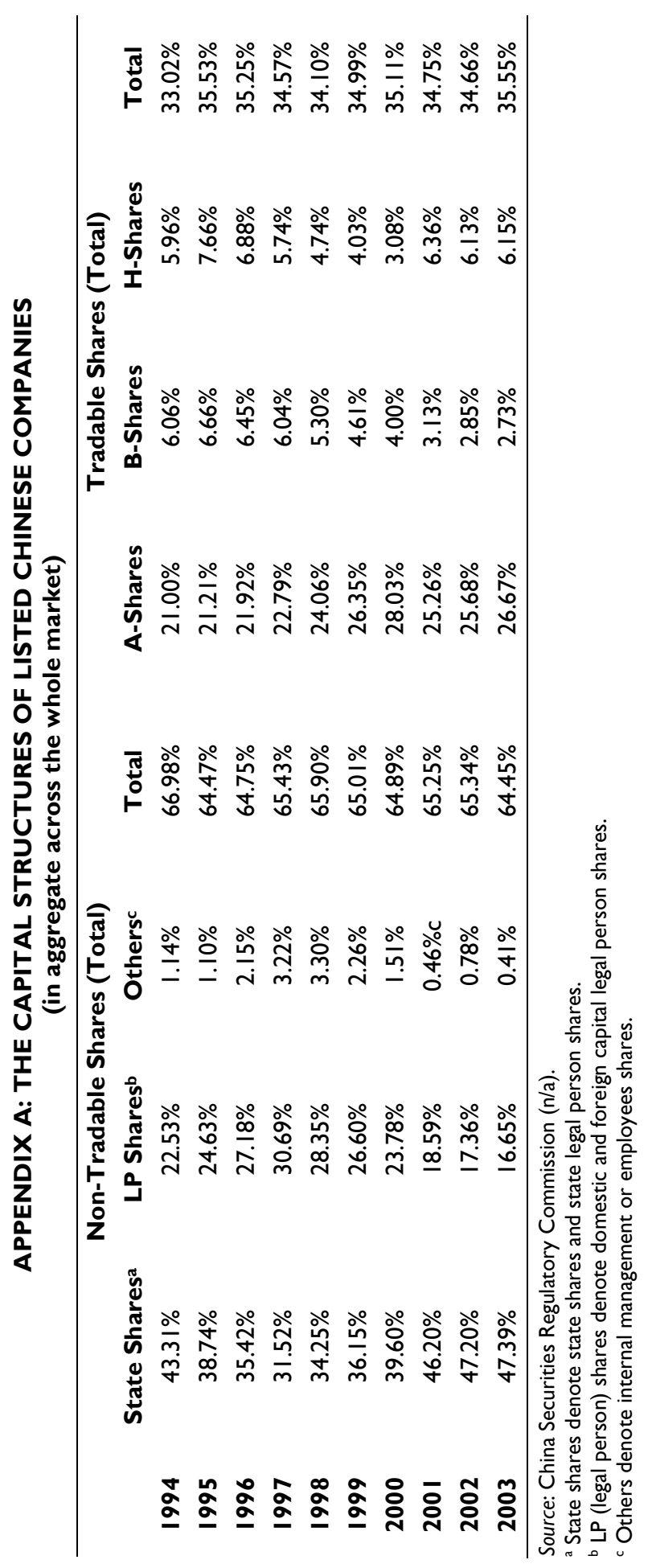


Kung, James and Cheng

\section{NOTES}

1. Ball and Shivakumar (2005) and Ball et al. (2000) refer to this asymmetric loss recognition timeliness characteristic as 'conditional conservatism', which can increase contracting efficiency and effectively capture much of the transparency of financial information, in contrast to 'unconditional conservatism', which is an accounting bias towards reporting low book values.

2. We consider only the profit figures computed using international financial reporting standards (IFRS) or Hong Kong's generally accepted accounting principles (GAAP) and not the figures produced under Chinese GAAP by the overseas-listed firms.

3. Bushman and Piotroski (2006, p. II7), in the largest scale cross-country empirical study on conservative reporting undertaken to date, exclude China and Poland from their 38 countries due to these countries' 'socialist legal origin'. Ball et al. (2003) also do not study China.

4. The quality of IFRS and Hong Kong GAAP are considered equivalent in quality to contemporary common law standards (Ball et al., 2003).

5. The fact that a majority of listed companies in China evolved from SOEs means that a high proportion of their capital consists of non-tradable state-owned and legal persons (LP) shares. In 2003, the percentage of all non-tradable (tradable) shares for China as a whole was 64.45 per cent (35.55 per cent). This percentage does not appear to be declining over time. Appendix A provides information about the capital structure of listed Chinese companies in aggregate in terms of the percentage breakdowns between shares held by the state, legal persons and other (all non-tradable); and between $\mathrm{A}$-, $\mathrm{B}$ - and $\mathrm{H}$-shares (all tradable).

6. This model has been widely used in recent empirical literature on accounting conservatism, including papers by Basu (1997), Pope and Walker (1999), Ball et al. (2000, 2003), Giner and Rees (200I), Bushman and Piotroski (2006), and Balkrishna et al. (2007). Critics of the Basu model are unable to explain why the ranking of reported conditional conservatism coefficients across countries in studies such as Ball et al. (2000, 2003), Bushman and Piotroski (2006), and the present paper are exactly in accordance with what the conservatism theory predicts. It is hard to believe that this could happen by chance, which would be the case if the Basu model does not actually capture differences in conditional conservatism (Ball, Kothari and Nikolaev, 2010, p. 28). Readers are referred to Ball et al. (20I0) for a detailed discussion and convincing refutation of the main criticisms (or, in their words, 'misconceptions' (p. 4)) of Basu's model.

7. Ryan (2006) suggests that to minimise the biases described by Dietrich, Muller and Riedl (2007), we use fiscal year returns in Basu's model.

8. Prior empirical studies using alternative models to Basu to measure conditional conservatism report equivalent results to those reported when Basu's model is used (Ball et al., 20 I0, pp. 24, 26). These alternative tests, such as the time-series of earnings changes test, have important deficiencies of their own (Ball et al., 2010, p. 25). Hence we do not undertake these additional tests.

9. According to Roychowdhury and Watts (2007), the Basu model slope coefficient is simply one measure of conditional conservatism and one that has limitations in that it is based on singleyear data for each firm-year observation. It is not conservatism per se. Roychowdhury and Watts (2007, p. 10) define NAc or 'true conservatism' as the difference between end-of-period net assets value (NAV) and book value of net assets (NAB). NAc is based on the full period of the firm's life following its initial public offering (see also their Figure I, p. 7).

10. All Chinese companies have calendar fiscal years, so stock returns are measured from May of the year $t$ to April of year $t+1$.

11. The industry classification adopted is CSRC for matching non-overseas-listed Chinese companies and the Hong Kong Standard Industrial Classification for matching Hong Kong companies.

12. As with Table 3 (Hong Kong companies), Panels A and B are for the entire population of this market that have sufficient accounting and stock price data, i.e. before the matching with the overseas-listed Chinese companies is performed. 
13. The standard deviations of both $R$ and $N I$ in the Chinese sample are very similar to the sample in Ball et al. (2000) and to those of the four East Asian country samples in Ball et al. (2003).

14. To assess the statistical significance for $\left(\beta_{5}+\beta_{6}\right)$, the following equation is used to calculate the $t$-statistic $\left(t^{*}\right)$ :

$$
\text { if } \hat{\beta}_{i} \sim N\left(\beta_{i}, \sigma_{i_{i}}^{2}\right) \text { then } \overline{\hat{\beta}}=\frac{\hat{\beta}_{5}+\hat{\beta}_{6}}{2} \sim N\left(\frac{\beta_{5}+\beta_{6}}{2}, \frac{\sigma_{\beta_{5}}^{2}+\sigma_{\beta_{6}}^{2}}{4}\right) t^{*}=\frac{\beta_{5}+\beta_{6}}{\sqrt{\frac{\sigma_{\beta_{5}}^{2}+\sigma_{\beta_{6}}^{2}}{4}}}
$$

\section{REFERENCES}

Akerlof, G. (1970). The Market for 'Lemons': Quality Uncertainty and the Market Mechanism., Quarterly Journal of Economics, Vol. 89, No. 3, pp. 488-500.

Ali, A. and Hwang, L. (2000). Country-Specific Factors Related to Financial Reporting and the Value Relevance of Accounting Data, Journal of Accounting Research, Vol. 38, No. 1, pp. $1-21$.

Balkrishna, H., Coulton, J. and Taylor, S. (2007). Accounting Losses and Earnings Conservatism: Evidence from Australian GAAP, Accounting and Finance, Vol. 47, No. 3, pp. 381-400.

Ball, R., Kothari, S.P. and Nikolaev, V. (2010). Econometrics of the Basu Asymmetric Timeliness Coefficient and Accounting Conservatism, Chicago Booth research paper no. 09-16, available from: <http:/ / ssrn.com/abstract $=999710>$, last accessed 10 February 2010.

Ball, R., Kothari, S.P. and Robin, A. (2000). The Effect of International Institutional Factors on Properties of Accounting Earnings, Journal of Accounting and Economics, Vol. 29, No. 1, pp. 1-52.

Ball, R., Robin, A. and Sadka, G. (2008). Is Financial Reporting Shaped by Equity Markets or by Debt Markets? An International Study of Timeliness and Conservatism, Review of Accounting Studies, Vol. 13, Nos. 2-3, pp. 168-205.

Ball, R., Robin, A. and Wu, J. (2003). Incentives versus Standards: Properties of Accounting Income in Four East Asian Countries, Journal of Accounting and Economics, Vol. 36, Nos. 1-3, pp. 235-270.

Ball, R. and Shivakumar, L. (2005). Earnings Quality in UK Private Firms: Comparative Loss Recognition Timeliness, Journal of Accounting and Economics, Vol. 39, No. 1, pp. 83-128.

Bartov, E. and Bodnar, G. (1996). Alternative Accounting Methods, Information Asymmetry and Liquidity: Theory and Evidence, The Accounting Review, Vol. 71, No. 3, pp. 397-418.

Basu, S. (1997). The Conservatism Principle and the Asymmetric Timeliness of Earnings, Journal of Accounting and Economics, Vol. 24, No. 1, pp. 3-37.

Beaver, W.H. and Ryan, S.G. (2005). Conditional and Unconditional Conservatism: Concepts and Modeling, Review of Accounting Studies, Vol. 10, Nos. 2-3, pp. 269-276.

Beck, T., Demirgüç-Kunt, A. and Levine, R. (2003). Law and Finance: Why Does Legal Origin Matter?, Journal of Comparative Economics, Vol. 31, No. 4, pp. 653-675.

Beekes, W., Pope, P. and Young, S. (2004). The Link between Earnings Timeliness, Earnings Conservatism and Board Composition: Evidence from the UK, Corporate Governance, Vol. 12, No. 1, pp. 47-59.

Boone, J. and Raman, K. (2001). Off-Balance Sheet R\&D Assets and Market Liquidity, Journal of Accounting and Public Policy, Vol. 20, No. 2, pp. 97-128.

Bushman, R.M. and Piotroski, J.D. (2006). Financial Reporting Incentives for Conservative Accounting: The Influence of Legal and Political Institutions, Journal of Accounting and Economics, Vol. 42, Nos. 1-2, pp. 107-148.

Census and Statistics Department (2003). Key Economic and Social Indicators, Hong Kong SAR, available from: <http://www.censtatd.gov.hk/>, last accessed 15 November 2010. 
Kung, James and Cheng

Chandra, U., Wasley, C.E. and Waymire, G.B. (2004). Income Conservatism in the U.S. Technology Sector, Simon School working paper No. FR 04-01, available from: <http://ssrn. com/abstract $=485064>$, last accessed 20 October 2009.

China Securities Regulatory Commission (n/a). Securities Market Statistics, available from: <http://www.csrc.gov.cn/pub/csrc_en/marketdata/>, last accessed 15 November 2010.

DeFond, M., Wong, T. and Li, S. (2000). The Impact of Improved Auditor Independence on Audit Market Concentration in China, Journal of Accounting and Economics, Vol. 28, No. 3, pp. 269-305.

Devine, C. (1963). The Rule of Conservatism Reexamined, Journal of Accounting Research, Vol. 1, No. 2, pp. 127-138.

Dietrich, J.R., Muller III, K.A. and Riedl, E.J. (2007). Asymmetric Timeliness Tests of Accounting Conservatism, Review of Accounting Studies, Vol. 12, No. 1, pp. 95-124.

Doidge, C. (2004). U.S. Overseas Listings and the Private Benefits of Control: Evidence from Dual-Class Firms, Journal of Financial Economics, Vol. 72, No. 3, pp. 519-553.

Doupnik, T. and Salter, S. (1995). External Environment, Culture, and Accounting Practice: A Preliminary Test of a General Model of International Accounting Development, International Journal of Accounting, Vol. 30, No. 2, pp. 189-207.

García Lara, J.M., García Osma, B. and Mora, A. (2005). The Effect of Earnings Management on the Asymmetric Timeliness of Earnings, Journal of Business Finance E Accounting, Vol. 32, Nos. 3-4, pp. 691-726.

Giner, B. and Rees, W. (2001). On the Asymmetric Recognition of Good and Bad News in France, Germany and the United Kingdom, Journal of Business Finance E Accounting, Vol. 28, Nos. 9-10, pp. 1285-1331.

Gul, F.A. (2006). Auditors' Response to Political Connections and Cronyism in Malaysia, Journal of Accounting Research, Vol. 44, No. 5, pp. 931-963.

Han, S. (1976). Wind in the Tower: Mao Tse Tung and the Chinese Revolution 1949-1976, London: Jonathon Cape.

Hong Kong Society of Accountants (2003). Premier Zhu Headlines World Congress Opening Ceremony, The Hong Kong Accountant, Vol. 14, No. 1, pp. 18-19.

Huijgen, C. and Lubberink, M. (2005). Earnings Conservatism, Litigation and Contracting: The Case of Cross-Listed Firms, Journal of Business Finance \& Accounting, Vol. 32, Nos. 7-8, pp. 1275-1309.

Hung, M., Wong, T.J. and Zhang, T. (2008). Political Relations and Overseas Stock Exchange Listing: Evidence from Chinese State-Owned Enterprises, working paper, University of Southern California, the Chinese University of Hong Kong and City University of Hong Kong, available from: <http://ssrn.com/abstract=1224162>, last accessed 18 December 2009.

Lai, C. and Taylor, S.L. (2008), Estimating and Validating a Firm-Year-Specific Measure of Conservatism: Australian Evidence, Accounting and Finance, Vol. 48, No. 4, pp. 673-695.

La Porta, R., Lopez-de-Silances, F., Shleifer, A. and Vishny, R. (1998). Law and Finance, Journal of Political Economy, Vol. 106, No. 6, pp. 1113-1155.

Mueller, G. (1967). International Accounting, New York, NY: Macmillan.

Nobes, C. (1983). A Judgmental International Classification of Financial Reporting Practices, Journal of Business Finance \& Accounting, Vol. 10, No. 1, pp. 1-19.

Pope, P.F. and Walker, M. (1999). International Differences in the Timeliness, Conservatism and Classification of Earnings, Journal of Accounting Research, Vol. 37 (Supplement), pp. 53-87.

Rajan, R. and Zingales, L. (2003). The Great Reversals: The Politics of Financial Development in the 20th Century, Journal of Financial Economics, Vol. 69, No. 1, pp. 5-50. 
Raonic, I., McLeay, S. and Asimakopoulos, I. (2004). The Timeliness of Income Recognition by European Companies: An Analysis of Institutional and Market Complexity, Journal of Business Finance E Accounting, Vol. 31, Nos. 1-2, pp. 115-148.

Roëll, A. (1996). The Decision to Go Public: An Overview, European Economic Review, Vol. 40, Nos. 3-5, pp. 1071-1081.

Roychowdhury, S. and Watts, R.L. (2007). Asymmetric Timeliness of Earnings, Market-toBook and Conservatism in Financial Reporting, Journal of Accounting and Economics, Vol. 44, No. 1, pp. 2-31.

Ryan, S.G. (2006). Identifying Conditional Conservatism, European Accounting Review, Vol. 15, No. 4, pp. 511-525.

Stevanovic, V. (2004). Milosevic: The People's Tyrant, London: I.B. Tauris.

Stulz, R. (1999). Globalization of Equity Markets and the Cost of Capital, Journal of Applied Corporate Finance, Vol. 12, No. 3, pp. 8-25.

Sun, Q. and Tong, W. (2000). The Effect of Market Segmentation on Stock Prices: The China Syndrome, Journal of Banking \& Finance, Vol. 24, No. 12, pp. 1875-1902.

Sunder, S. (1997). Theory of Accounting and Control, Cincinnati, OH: South-Western College Publishers.

Wallace, R. and Naser, K. (1995). Firm-Specific Determinants of the Comprehensiveness of Mandatory Disclosure in the Corporate Annual Report of Firms Listed on the Stock Exchange of Hong Kong, Journal of Accounting and Public Policy, Vol. 14, No. 4, pp. 311-368.

Watts, R. (2003a). Conservatism in Accounting Part I: Explanations and Implications, Accounting Horizons, Vol. 17, No. 3, pp. 207-221.

Watts, R. (2003b). Conservatism in Accounting Part II: Evidence and Research Opportunities, Accounting Horizons, Vol. 17, No. 4, pp. 287-301.

Xiao, J., Zhang, Y. and Xie, Z. (2000). The Making of Independent Auditing Standards in China, Accounting Horizons, Vol. 14, No. 1, pp. 69-89.

Zinov'ev, A. (translated by C. Janson) (1985). Reality of Communism, London: Paladin Books. 